\title{
INTEGRATING HUMAN RELATION SKILLS INTO THE CURRICULUM OF INDUST RIAL TECHNOLOGY RELATED PROgRAMS
}

\author{
Heshium Lawrence \\ Department of HRD and Technology, Tyler, TX
}

\begin{abstract}
Technological devices are playing such a significant role in our lives that educators are incorporating Ipads, smartphones, and even Skyping via these devices to educate our future generations. Managing the utilization of this technology has become an important issue for businesses and proposes the question: how is it possible to maintain good human relations with customers, clients and other businesses with all of the technological advancements that often prevent face-to-face interaction? This paper addresses the value of assimilating human relation skills into the curriculum of Industrial Technology related programs. Additionally, this article provides an overview of Industrial Technology related programs and will also address how to differentiate between Human Resource Development programs and Human Resource Management programs.
\end{abstract}

\section{KEYWORDS}

Industrial Technology, Human Relations, Management, Applied Engineering, Curriculum

\section{INTRODUCTION}

Technology is so prevalent today that it affects all aspects of our lives, from a bed that adjusts to the way an individual sleeps to automobiles that literally parallel park themselves. Businesses adapt and change their infrastructure[s] [14] to improve their technological skills and incorporate new methods of obtaining information in order to survive and stay competitive in today's technology-dependent environments. McGrath stated that American Airlines started using a computerized flight booking system and Bank of America took on an automated checkprocessing system [13] in order to stay competitive. The advancement of technology has allowed smartphones to send and receive emails, check stock quotes, remotely arm and disarm home security systems, and allow the use of Microsoft Office applications. Managing the utilization of this technology has become an important issue for businesses and proposes the question: how is it possible to maintain good human relations with customers, clients and other businesses with all of the technological advancements that often prevent the face-to-face interaction?

The field of Industrial Technology was developed in the late 1960's to produce technical professionals with managerial skills who could improve productivity to keep up with demand for technology related products. In addition, students who graduated in the mid- $20^{\text {th }}$ century did not obtain the necessary skills to incorporate technology and business practices. It was during the 1950's that these graduates began taking industrial management jobs. Zargari \& Coddington noted that:

Technological developments in industries created new occupations that required a balance between management knowledge and technical skills. This has become the technical-management profession - 'management' jobs with a decidedly 'technical' nature. The discipline of Industrial 
International Journal on Integrating Technology in Education (IJITE) Vol.3, No.1, March 2014

Technology was established to meet the needs of business and industry for employees who could use the complex tools of production and at the same time were able to manage personnel and facilities. [23]

The demand for professional industrial personnel with higher education, technical application skills and leadership qualities increased as engineering programs offered less laboratory application courses [9]. The field of Industrial Technology, also referring to programs now titled Technology Management and Applied Engineering, prepares students for management-oriented positions in industry, business, education and government [19]. Industrial Technology related curricula cover a wide range of content which contains courses on quality, electronics, safety, maintenance, and management. Although it is important for the students to have practical skills in the business environment, they should also incorporate human relation skills as well. This will ensure that students possess the pertinent soft skills such as effective communication with coworkers and peers, working together in a team environment, and having the ability to resolve conflicts. Companies are not only considering individuals who have the ability to execute handson technical tasks but also the ability to be attentive and articulate their concerns or questions effectively with their managers, supervisors, and co-workers. Moreover, having outstanding interpersonal abilities in the workplace will support the individual in excelling in the workplace. Further, these individuals need to have the ability to motivate themselves and others to work more efficiently and increase productivity to keep pace with global competition.

\section{Evolution of Industrial Technology Related Programs}

Technology education in the United States is presumed to have been founded in the early twentieth century as Industrial Arts, but there are historic roots that date the field back much further than that. Industrial Arts can be depicted as an extension of those founding roots as opposed to a philosophical convergence of them. It was Lois Coffey Mossman and Frederic Gordon Bonser who had the greatest influence on the origins of what is now known as technology education [7]. Industrial Arts evolved from the term manual training. The field of Manual Training had a threefold purpose in the nineteenth century; its objectives were to keep boys in school, provide vocational skills, and develop leisure-time interests [8]. Manual Training later grew to include objectives which incorporated instruction in the fundamental principles, processes, and materials of industry. Over the years Americans embraced a learning by doing approach [3]. Industrial Arts Education, now known as Industrial Education, focused on the idea that students should learn about technologies that affected them both personally and commercially and that this knowledge will adequately prepare them for a society that was becoming technology-driven. This led to an increase in graduates taking on industrial management jobs; however, it became evident that just possessing knowledge in the industrial arts was not sufficient enough to excel in the workplace; consequently, the field of Industrial Technology was created. While Industrial Arts programs concentrated on technology and psychology, Industrial Technology programs united the facets of technology and management. Most programs require a number of management-related courses or a minor in Business Administration. Moreover, ATMAE accreditation standards require a certain number of hours in technology and management related course work in order for programs to become accredited [1].

The field of Industrial Technology is beginning to run its course, and many of the programs have evolved and changed their name to technology management, applied engineering or some combination of these words. According to Minty, Industrial Technology is approaching a junction in its journey from conception, incubation, early development and full development, and health as a discipline [16]. The discipline of Industrial Technology has evolved over time like its predecessors to accommodate the ever changing workforce and demands of society. When the National Association of Industrial Technology (NAIT) changed its name to the Association of 
Technology, Management, and Applied Engineering (ATMAE) in 2010, the field of Industrial Technology became one of several disciplines that ATMAE served. The association was able to widen its focus to contain Applied Engineering, Technology Management, Engineering Technology, Operations Management, and Engineering Management curriculums including numerous other programs related to technology. ATMAE was developed to provide recognition of the attainment of certain professional goals and standards for Industrial Technology and to encourage others to strive toward these goals and standards [1]. The new direction for Industrial Technology has begun to emphasize management and applied engineering. Students must study content areas in management and technology and the impact that these two areas will have or currently have on society. There has become a tri-fold focus for those who are pursuing or wish to pursue a degree in Industrial Technology. In fact, according to Wright's Venn diagram which is linked to the ATMAE website under the About ATMAE tab, Management, Technology and Applied Engineering are listed as the main content areas, and Industrial Technology is no longer even listed as a main discipline in the overlapping content areas. Technology Management, Applied Engineering, Engineering Technology, Technology, Management and Engineering Managemenare the only areas listed on the diagram as illustrated in Figure 1.

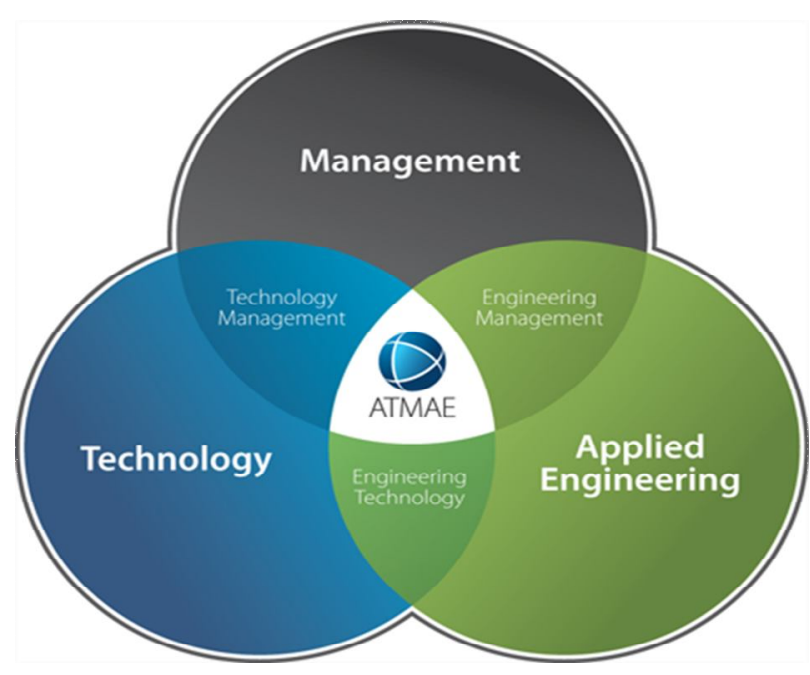

Figure 1: ATMAE Membership Venn Diagram

According to Wright on his Venn diagram (personal communication, June 8, 2012),

the overlapping fields are just those that are comprised of the three big circles. All fields listed on the Venn diagram are what I would consider anchor programs that illustrate ATMAE's realm for accreditation and membership interest. The Venn diagram is merely a communication tool to show folks what we (our profession) do and what general types of members and programs exist under our umbrella.

In other words, ATMAE is more than just an association for Industrial Technology programs as was indicated by the former name of the profession, National Association of Industrial Technology.

According to the Classification of Instructional Programs (CIP) definition provided by the U.S. Department of Education Institute of Education Sciences, Engineering Technology instructional programs prepare individuals to apply basic engineering principles and technical skills in support 
of engineering and related projects. [20] These programs are basically engineering programs with reduced math requirements and more "hands-on" laboratory work. There is little focus on management and more on math. According to Mier, Williams, Humphreys, and Centko, traditionally Industrial Technology departments have produced graduates with very strong technical skills [15] and now with the new emphasis areas, graduates will not only have strong technical skills but strong engineering concepts as well. Another area that is showing promise in the field of Industrial Technology is management, and since Industrial Technologists are prepared to succeed in technical management-oriented professions, this area is of the utmost importance.

Engineering Management is defined by John Wright (personal communication, October 20, 2010) as the curriculum area concentrating on the use of engineering principles to the planning and operational management of industrial and manufacturing operations. This field includes instruction in accounting, economics, finance, human resources management, industrial psychology, management information systems, mathematical modeling and optimization, quality control, operations research, safety and health issues, and environmental management [21]. It should be noted that John Wright was consulted by the author because of his pivotal role in changing the association for Industrial Technology from NAIT to ATMAE.

Many companies are emphasizing the development of teamwork, group project skills, and problem solving skills as a result of the increased global focus on total quality management and statistical quality control concepts. Mier et al. state that, with the increase in management and people skills expected by business and industry leaders, there is a need to examine the balance between the technical and management foundation requirements [of Industrial Technology students ] [15]. The inclusion of Management in fields, such as Engineering Management, Operations Management, and Technology Management, along with Industrial Technology is becoming widely accepted and an area that has a promising future for Industrial Technology related majors. Individuals will have the capability of expanding what they have learned in these management fields and skill set to aspects relating to business and industry. The other field that is impacting Industrial Technology is engineering, and according to Lawrence's research on alumni perceptions of the Industrial Technology undergraduate program at Mississippi State University, he ascertained that the majority of the Industrial Technology alumni obtain jobs in engineering fields. The only problem was that Industrial Technology majors did not have an engineering background. However, most employers from industries viewed Industrial Technologists as engineers, therefore giving them engineering type assignments [12].

Future Industrial Technologists will face more challenges and changes as society adjusts and businesses and industries require more innovative ways to make a profit. The name change from the National Association of Industrial Technology to the Association of Technology, Management, and Applied Engineering is evident of societal change, and the ATMAE Executive Board acknowledged that change and began making progress in keeping up with the direction of the field of Industrial Technology. Schaar (n.d), noted:

The future is not a result of choices among alternative paths offered by the present, but a place that is created--created first in the mind and will, created next in activity. The future is not some place we are going to, but one we are creating. The paths are not to be found, but made, and the activity of making them, changes both the maker and the destination [18]

With the help of ATMAE, the field of Industrial Technology is definitely headed in the right direction. The path that the field has embarked upon is becoming more defined, and students are reaping the benefits of its future exploration. Industrial Technology programs now integrate the features of Industrial Arts curriculum married with technological and managerial skills to 
accommodate the needs of industry. Moreover, Industrial Technology, according to ATMAE is primarily involved with:

the application of basic engineering principles and technical skills in support of industrial engineers and managers. Industrial Technology degreed programs typically include instruction in optimization theory, human factors, organizational behavior, industrial processes, industrial planning procedures, computer applications, and report and presentation preparation [1]

\section{THE IMPORTANCE OF HUMAN RELATIONS SKILLS}

Managers are constantly communicating with their employees, and having effective communication skills is imperative. Human relation is the study of the interactions that exist between people. These relationships, both formal and informal, occur both in our personal and our work lives [6]. Similarly, Lamberton and Minor-Evans provide a more robust description of human relations and its role in industry:

Human relations includes a desire to understand others, their needs and weaknesses and their talents and abilities. For everyone in a workplace setting, human relations also involves an understanding of how people work together in groups, satisfying both individual needs and group objectives. If an organization is to succeed, the relationship among the people in the organization must be monitored and maintained. [11]

As previously stated by Lamberton and Minor-Evans, understanding others enables individuals to communicate with them better.[11] In business, for example, an individual may be partnered with someone in a group who is not comfortable operating in a particular setting; however, if there are open lines of communication individuals can become more productive and contribute to the organization. Although human relation skills need to be addressed in Industrial Technology, the importance of Industrial Technology should not be overlooked. As mentioned before, Industrial Technology is an area of study designed to teach both technical and management skills. It prepares managerial professionals for employment in business, industry, education, and government.

To summarize, Industrial Technology was created from the idea of manual training for the motives that Manual Training programs did not offer students the needed skill sets to propel them in a workplace environment that was industrial. Manual Training did not provide any form of instruction in regards to management and organizational structure. The students learned in an authoritarian type of environment, and expressing one's self in Manual Training programs was discouraged as was the concept of initiative. The product was the only thing that Manual Training programs were concerned with. On the other hand, Industrial Technology curriculum looks at the student as the product and how that student could be a productive individual to the workforce and society. Industrial Technology curriculum allows the students to express themselves freely and be creative.

When the field of Industrial Technology's professional association changed its name from the NAIT to ATMAE, the intent was to broaden its scope to include all of the new disciplines that have evolved from it such as Technology Management, Applied Engineering, and Engineering Management. With the addition of these fields as offshoots from the field of Industrial Technology, graduates of these programs will now have management skills and know how to put that knowledge into practice. With this knowledge, according to Ulrich \& Brockbank, they will be able to add value to strategic discussions that involve technology.... [19]. 
Human relations refers to how we interact with and co-exist with people. It is the study of relationships among people [4]. The relationships developed with people can evolve in organizational or personal settings. That relationship can also be intimate or distant, one-on-one, or within groups. How we as individuals communicate with people equally in official and relaxed behaviors is the pedagogy of human relations. The more that is understood about what stimulates individuals and what has an effect on their morale or work performance, the stronger an individual's human relations skills will become. Some key elements of good human relations skills include being aware of the sources and uses of power, gaining problem solving and decision making skills, and understanding creativity, team building, and legal and ethical considerations [4]. As Industrial Technology promotes students to become managers or supervisors, it is important that they know how to communicate effectively and efficiently in industry. Becoming a manager or a supervisor not only means understanding one's industry but also understanding how to interact with employees and peers. In addition to communication skills, industrial technologists need to acquire effective team work and strong leadership skills as well as problem solving skills. Problem solving is particularly important because in any social institutions, conflict is bound to arise; thus, managers in industry must be able to assess and quickly resolve discord.

Furthermore, human relations skills may be the most significant impact on the achievement or disappointment of an individual's career. The Carnegie Foundation stated, 85 percent of the factors contributing to our job success are personal qualities, while technical knowledge contributes only 15 percent. [4]. The Harvard Bureau of Vocational Guidance reported that 66 percent of people fired from their jobs were fired because they did not get along with others while only 34 percent because of lack of technical knowledge. [5]. Table 1, which was adapted from Redman, Montgomery, \& Penn, lists some of the desired skills that employers are looking for from recent graduates. [17]

Table 1. Skills That Employers Want

\begin{tabular}{|l|l|}
\hline Type of Skill & Employers' requirements-'Buzz' words \\
\hline \multirow{5}{*}{ Self-reliance skills } & Self-awareness - purposeful, focused, \\
self-belief, realistic \\
Proactivity - resourceful, drive, self-reliant \\
Willingness to learn - inquisitive, motivated, \\
enthusiastic \\
Self-promotion - positive, persistent, ambitious \\
Networking - initiator, relationship-builder, \\
resourceful \\
Planning action - decision-maker, planner, able \\
to prioritize
\end{tabular}


International Journal on Integrating Technology in Education (IJITE) Vol.3, No.1, March 2014

\begin{tabular}{|l|l|}
\hline General employment skills & $\begin{array}{l}\text { Problem-solving - practical, logical, results } \\
\text { orientated } \\
\text { Flexibility - versatile, willing, multi-skilled } \\
\text { Business acumen - entrepreneurial, competitive, } \\
\text { risk taker } \\
\text { IT/computer literacy - office skills, keyboard skills, } \\
\text { software packages } \\
\text { Numeracy - accurate, quick-thinker, methodical } \\
\text { Commitment - dedicated, trustworthy, conscientious }\end{array}$ \\
\hline Specialist skills & $\begin{array}{l}\text { Specific occupational skills - specialist relevant } \\
\text { knowledge, e.g. languages, IT } \\
\text { Technical skills - e.g. journalism, engineering, } \\
\text { accounting, sales }\end{array}$ \\
\hline
\end{tabular}

As the table illustrates, people skills as well as problem-solving skills are increasingly important and are part of human relation pedagogy. With the inclusion of human relation pedagogy, Industrial Technologists will not only be able to interact on an industrial level, i.e., technical, but also on an interpersonal level. Human relations pedagogy empowers managers, supervisors, and co-workers to express their instructions or ideas in an effective and constructive manner, thereby enabling their employees to work efficiently and without any confusion.

\section{INTEgRating Human Relation Skills into INDUSTRIal TECHNOLOGY CURRICULUM}

Integrating human relation skills with Industrial Technology related program curriculum is very important in industry. The question, however, is how to seamlessly integrate the two. There are several ways in which this can be implemented, but first it is necessary to consider two important questions?

First, how is the value of human relation being defined? Understanding the value of human relations is the foundation to determining how to assimilate it with industrial technology pedagogy; according to Ulrich \& Brockbank, value is defined by the receiver, not the giver, any value proposition begins with a focus on receivers, not givers [19]. It is important that instructors in the field of Technology, Management, and Applied Engineering understand this definition in order to produce effective and efficient managers and supervisors. Once this has been accomplished, industrial technologists in the positions of managers or supervisors will be successful in creating human abilities and organizational capabilities that generate products, services, and results that customer and capital markets demand [19].

Second, what area of industry and business are integrating human relations skills? According to Dalton et al. the human relation skills needed include the use of teamwork to work together effectively to meet production and delivery deadlines and maintain quality. Use other skills such as motivation, goal setting, job performance, problem solving, and decision making [4].

It should be noted that most ATMAE accredited Industrial Technology related programs require a number of management courses or even a minor in Business Administration. However, unless students are taking Human Resource Development or Human Resource Management courses, they may not be given any instruction in human relations. Coordinators of Industrial Technology related programs, who are responsible for the progress of courses, should be conscious of the 
differences among the development and training of personnel, which is Human Resource Development and the approach of managing that personnel, which is Human Resource Management.

Most Human Resource Management courses focus on the management of hiring qualified personnel for the purpose of filling vacant positions. Activities involved with the department include advertising and posting, recruiting, staffing, interviewing, hiring, terminations, layoffs, career training, and performance reviews of company employees. These are a lot of topics to be covered in one course; therefore, not much time can be dedicated to human relation skills [2].

On the other hand, Human Resource Development (HRD) course work is synonymous with performance improvement or motivating individuals to do their best and increase human potential [10]. HRD course work devotes more time to human relation skills while HRM courses focus more on the hiring, firing, labor laws, benefits packages, and other activities related to maintaining an adequate workforce. Motivating employees to always strive to improve is instrumental in implementing continuous improvement programs to keep companies globally competitive. Human relation skills go hand-in-hand with Six Sigma Lean philosophies and are essential to the new curricula of Industrial Technology related programs such as Technology Management and Applied Engineering.

The integration of human relation skills can be accomplished in Industrial Technology related curricula by using several methods: implementing more core courses on human relation skills, allowing more projects that are problem-based to be solved in group settings, and providing Industrial Technology students with the opportunity for more practical experiences such as internships or co-ops. Some other ways that the concept of human relations can be assimilated into the curriculum is by teaching the student that understanding the goals of an organization can assist them in developing the necessary communication skills needed in that organization. Similarly, teaching students that communicating with clients and customers in industry helps to enhance their human relation skills and will also allow them to establish rapport with clients or customers. In addition, integrating human relations with Industrial Technology curriculum can also be established by coordinating work with others in the classroom. This can help the student to transfer the concept of coordination from the classroom to the industrial organization.

\section{CONCLUSION}

Industrial Technology related curriculum enables the learner to understand and work in a technical environment as well as enhances the ability to manage or supervise in that arena. With the rapid changes seen in today's society, human relation skills are just as valuable as possessing the technical skills. Knowledge of how to effectively communicate with others is a requirement in business and industry. It is important that technologists and applied engineers not only acquire the technical skills but also be effective in communicating those skills to co-workers or peers. Industrial Technology related programs will greatly benefit from implementing the aforementioned methods of assimilating human relations into the curriculum. The end result will afford educators of this field the opportunity to see first hand how human relation skills are vital to technologists and applied engineers that they are sending out into the real world to be future managers or supervisors.

The skills that Industrial Technology majors will now acquire, with the addition of the human relations curriculum, will set them apart from the current managers or supervisors in the technical environment. They will be able to bring relevant human relations skills to that business or industry, including better interpersonal skills and better conflict resolution skills. Human relations skills will also help them be successful in their careers. It is important that human relation skills 
International Journal on Integrating Technology in Education (IJITE) Vol.3, No.1, March 2014

are integrated into Industrial Technology related curriculum because the students deserve to acquire the knowledge needed to communicate effectively and efficiently. Moreover, they need to have the opportunity to advance in their careers as a result of the excellent human relations skills they will possess. Industrial Technology related programs produce managers and supervisors, so it is crucial that they know how to communicate instructions and authority effectively and successfully, how to work in a team environment, how to work towards accomplishing stated goals, how to maintain the mission of a particular industry or business, and most importantly motivate workers to be more productive to combat global competition.

\section{REFERENCES}

[1] Association of Technology, Management, and Applied Engineering. (2009). Industrial TechnologyAccreditation Handbook. Ann Arbor, MI: Author.

[2] Business Dictionary.com (2012). Definition of Human Resource Management. Retrieved from: http://www.businessdictionary.com/definition/human-resource-management-HRM.html

[3] Butts, R.F., (1955). A cultural history of Western education. New York, NY: McGraw-Hill.

[4] Dalton, M., Hoyle, D., \& Watts, M. (2000). Human relations (2nd ed.). Columbus, OH: SouthWestern Educations Publishing.

[5] Davenport, T. (1993). Process innovation: Reengineering work through information technology. Boston, MA: Harvard Business School Press.

[6] DeCenzo, D. \& Silhanek, B., (2002). Human Relations: personal and Professional Development (2nd ed.). Boston, MA: Prentice Hall.

[7] Foster, P.N., (1995). The founders of industrial arts in the US [Electronic version]. Journal of Technology Education, Vol. 7, No. 1, pp1-12.

[8] Gerbracht, C. \& Babcock, R., (1969). Elementary school industrial arts. New York: Bruce.

[9] Keith, C., \& Talbott, L. (1991). History of industrial technology. Ann Arbor, MI: National Association of Industrial Technology.

[10] Kelly D. (2001). Dual perceptions of HRD: Issues for policy: SME's, other constituencies, and the contested definitions of human resource development. Retrieved from http://ro.uow.edu.au/artspapers/26.

[11] Lamberton, L., \& Minor-Evans, L., (2002). Human relations strategies for success. Woodland Hills, CA: Glencoe/McGraw-Hill.

[12] Lawrence, H. (2010). An investigation of alumni perceptions of the Industrial Technology undergraduate program at Mississippi State University and its transferability to industry (Doctoral dissertation, Mississippi State University). Retrieved from http://library.msstate.edu/.

[13] McGrath, J. (n.d). How has technology changed the way we conduct business? Retrieved from http://money.howstuffworks.com/technology-changed-business1.htm

[14] McKenney, J. L., Copeland, D. C., Copeland, D. G., \& Mason, R. O. (1995). Waves of change: Business evolution through information technology. Harvard Business Press.

[15] Mier, R. L., Williams, M., Humphreys, M., \& Centko, J. (1999). An exploratory study to assess competency gaps in science, mathematics, engineering, and technological (STEM) education. Journal of Industrial Technology, Vol. 15, No. 3, pp1-8.

[16] Minty, G., (2004) The future history of industrial technology. Journal of Industrial Technology, Vol. 20, No. 1, pp1-8.

[17] Redman, J., Montgomer, J., \& Penn, D. (2011). What do graduates do? Retrieved from http://www.prospects.ac.uk/assets/assets/documents/WDGD_2011.pdf

[18] Schaar, J. (n.d). Retrieved from http://www.heartquotes.net/Change.html.

[19] The Association of Technology, Management, and Applied Engineering. (2009). The Association of Technology, Management, and Applied Engineering Accreditation Handbook. Ann Arbor, MI: Author

[20] Ulrich, D., \& Brockbank, W., (2005). The HR Value Proposition. Boston, MA: Harvard Business School Press.

[21] U. S. Department of Education Institute of Education Sciences: National Center for Educational Statistics (2002), CIP 2000: Engineering technologies/technicians. Retrieved from http://nces.ed.gov/pubs2002/cip2000/ciplist.asp?CIP2=15. 
International Journal on Integrating Technology in Education (IJITE) Vol.3, No.1, March 2014

[22] Wikipedia. (2010). Association of Technology, Management, and Applied Engineering. Retrieved from http://en.wikipedia.org/wiki/Engineering_management.

[23] Wikipedia. (2012). Human resource development. Retrieved from: http://en.wikipedia.org/wiki/Human_resource_development.

[24] Zargari, A., \& Coddington, C., (1999). Key characteristics of industrial technology faculty: A national survey of NAIT accredited IT programs [Electronic version]. Journal of Industrial Technology, Vol. 15, No. 2, pp1-6.

\section{Author}

Heshium Lawrence is an Assistant Professor at The University of Texas at Tyler in the Department of HRD and Technology. He currently teaches undergraduate and graduate courses in Six Sigma, Total Quality Management, and Project Management. He has research experience in the pedagogy of undergraduate students in Industrial Technology programs and is a Certified Lean Six Sigma Black Belt. He has a membership in the Association of Technology, Management, and Applied Engineering (ATMAE).

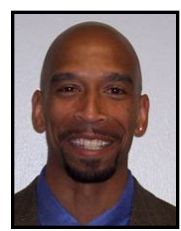

